\title{
A New Model of Supplier's Selection for Sustainable Supply Chain Management
}

\author{
Oussama El Mariouli*,Abdellah Abouabdellah
}

Systems Engineering Laboratory, MOSIL, ENSA, University Ibn Tofail, Kenitra, Morocco

\begin{tabular}{l} 
A R T I C L E I N F O \\
\hline Article history: \\
Received: 17 December, 2018 \\
Accepted: 04 March, 2019 \\
Online: 03 April, 2019
\end{tabular}

Keywords:

Supply Chain

Criteria

Sustainable development

Supplier selection

\begin{abstract}
A B S T R A C T
In the last years, industrial company began to understand the central role that plays sustainable supplier selection (SSS) process for obtaining a sustainable supply chain (SSC). This paper proposes a new multi-criterion decision-making (MCDM) model for managers, which makes it possible to select the best suppliers who respect the sustainable development (SD) concept for a SSC. We start our paper by selecting the most recent economic, environmental and social criterion used in researches. After, we develop a new model mathematic that take into consideration the SD criteria in sustainable supplier rank and selection. Finally, we present a case study for testing our model.
\end{abstract}

\section{Introduction}

Recently, most industrial companies adopt the strategy of integrating the SD policy into their supply chain (SC), from downstream (purchase) upstream (distribution) to remain competitive and open up to new international markets, this approach starts with the selection of suppliers who respect SD's dimensions: SSS is central to the management of an SSC $[1,2]$.

The new strategic direction of companies towards the SD concept, has required new economic, environmental and social criteria instead of conventional criteria (quality, cost and lead time) in purchasing decisions, therefore the process of supplier selection is has become a complex and multi-criteria decision that depends on several qualitative and quantitative criteria.

In this paper, we develop a new multi-objective mathematical model that allows measuring the index of supplier's sustainability for chooses the best between them. Our research methodology is articulated around two phases of realization, which we will detail them below:

- The first phase is the identification of recent SD criteria used to measure supplier performance;

- Last Phase present the equation that measures and rank sustainable supplier performance.

\section{Literature Review}

This section has four subsections. The first part presents a brief overview of the SSC management. The second part presents work

*Oussama El Mariouli, Email: oussama.el.mariouli@gmail.com on selection criteria. The last part presents the different vendor selection models found in the literature search and the last section presents the methods and approaches used in ranking the best SS.

\subsection{Sustainable supply chain management}

In the last 10 years, the SSC has become an important topic in the businesses and academies [3]. The role of the SSCM is to manage flows, information and cooperation among organizations throughout the supply network, taking into account economic, environmental and social criteria [4].

\subsection{Supplier selection criteria}

In the literature, we noticed that the selection criteria of suppliers change with the globalization and the appearance of the new concept such as Just-a-temp.

The first selection criteria for suppliers were made by Dickson (1966); he conducted a survey of 274 Canadian and American companies that are members of the National Association of Purchasing Managers (NAMP), and identified 23 criteria used by companies in the 1960s to select their suppliers [5].

The study by Weber and al. (1991) showed that these criteria remained the same until the 1990s, but the importance and the coefficient relative to each of the criteria are changed [6].

The study by Larson (1993) showed that the quality and the total cost of the product purchased are the most important criteria in the selection of suppliers [7].

The study by Vonderembse and al. (1995) out of 268 US companies, NAPM member has defined 10 important criteria used 
for the choice of suppliers; it has shown that these companies specify the performance and the quality of the product in the selection of the suppliers [8].

The study by Verma and al. (1998) on 323 US companies showed 4 criteria (quality, price, delay and flexibility) for the selection of suppliers [9].

The study by Katsikeas and al. (2004) out of 237 British companies showed that the choice of suppliers is based on 4 criteria (reliability of the delays, price competitiveness, service offered and technological capacity) [10].

The study by Aguezzoul and Ladet (2006) showed that the QCD triptych (quality, cost and delay) was the most used in the selection of suppliers [11].

The Baumann study (2011) defined 15 indicators to measure the sustainable development of the supply chain [12].

The study by Boukherroub and al (2013), inspired by Baumann (2011), defines 7 criteria for sustainable development because of their relevance in the scientific literature and international standards [13].

The study of Ouzlem and al. (2015) proposed a list formed by 8 main criteria and 31 ecological subscribers [14].

The study of Caron and al. (2016) identify 8 principles and 27 criteria of SD using in mineral exploration industry [15].

The study of Song and al. (2017) used 10 criteria to SSS for solar air-conditioner manufacturer [16].

The study of Vasiljević and all. (2018) proposed 20 criteria used to evaluate the supplier in automotive industry [17].

The study of Sureeyatanapas and al. (2018) proposed 39 supplier selection criteria [18]. The study of Memari and al. (2019) presented the top 10 economic, environmental and social criteria for SSS [19].

In the second section, we will give a new list of recent criteria used for the supplier selection in a context of sustainable development.

\subsection{Selection of suppliers}

Supplier selection is one of the most crucial decisions made by managers in organizations [20]. The decision has become multicriteria and very complex, it depends on qualitative and quantitative factors at the same time. Several research and literature reviews $[21-23,11]$ presented different methods and approaches for help buyers make the decision to select the best supplier. The table (Table1) presents the different methods of selection and evaluation of suppliers found in the literature.

In the literature, we find several recent researches that study the problem of the selection of suppliers. We can notice that:

- Most of this research does not include the three sustainable development dimensions in the supplier selection process; it focused only on green supplier problem [24-30].

- Most methods developed are complex to use.

- AHP is the most used method in the literature, but this method has the disadvantage of uncertainty of judgment.

In this study, our model developed has as originality:

- Integration of SD criteria most used in literature and internationals standards in the supplier selection process.

- Simple to apply and can be used in any industrial enterprise.

Table 1: Methods of selection and evaluation of suppliers

\begin{tabular}{|c|c|c|}
\hline \multicolumn{2}{|r|}{ Supplier selection method } & Disadvantage \\
\hline \multirow{4}{*}{ Artificial intelligence } & CBR (Case Based Reasoning system) & \multirow{4}{*}{$\begin{array}{l}\text { - The collection and processing of } \\
\text { supplier data by experts take a lot of } \\
\text { time. }\end{array}$} \\
\hline & ES (Expert System). & \\
\hline & NN (Neural Network) & \\
\hline & FST (Fuzzy Sets Theory) & \\
\hline \multirow[b]{2}{*}{$\begin{array}{c}\text { Statistical / } \\
\text { Probabilistic Models }\end{array}$} & CA (Cluster Analysis) & \multirow{2}{*}{$\begin{array}{l}\text { - Absence of optimal solution } \\
\text { - Difficulty of analysis } \\
\text { - Absence of the possibility of adding } \\
\text { mathematical constraints in the } \\
\text { model }\end{array}$} \\
\hline & FA (Factor Analysis) & \\
\hline \multirow{9}{*}{$\begin{array}{c}\text { Model of } \\
\text { mathematical } \\
\text { programming }\end{array}$} & DEA (Data Envelopment Analysis) & \multirow{9}{*}{$\begin{array}{l}\text { - Difficulty of dealing with subjective } \\
\text { criteria } \\
\text { - Absence of optimal solution } \\
\text { - Difficulty analyzing the result } \\
\text { obtained from the method }\end{array}$} \\
\hline & $\begin{array}{l}\text { GP (Goal Programming) or multi-objective } \\
\text { programming }\end{array}$ & \\
\hline & MOP (Multi Objectifs Pprogramming) & \\
\hline & AHP (Analytic Hierarchy Process) & \\
\hline & FST (Fuzzy Sets Theory) & \\
\hline & ANP (Analytic Network Process) & \\
\hline & $\begin{array}{l}\text { TOPSIS (Technique for the Order Performance } \\
\text { by Similarity to Ideal Solution) }\end{array}$ & \\
\hline & MAUT (Multiple Attribute Utility Theory) & \\
\hline & TCO (Total Cost Ownership) & \\
\hline $\begin{array}{l}\text { The categorical } \\
\text { method }\end{array}$ & $\begin{array}{l}\text { It relies on the experience and expertise of the } \\
\text { buyer }\end{array}$ & $\begin{array}{l}\text { - A subjective method } \\
\text { - Absence of the relative importance } \\
\text { of each criterion }\end{array}$ \\
\hline Hybrid models & $\begin{array}{l}\text { It represents the combination of two or more } \\
\text { methods of evaluation }\end{array}$ & - Computational complexity \\
\hline
\end{tabular}




\section{Methodology}

\subsection{Determining criteria for measuring sustainable supplier performance}

This paper aims to provide a broad synthetic analysis of an area that has experienced rapid growth in knowledge [40]. The data collected for this paper will help to identify the SD criteria that are cited in the various published research to define a useful theoretical overview to better understand SS phenomena.

The literature review follows a systematic methodology (Briner and Denyer 2012) to reduce the number of articles published and focuses on leading journals that publish SS research [41]. In our initial library research on relevant documents. we did an analysis of the different databases "ScienceDirect, Springer, Emerald, Taylor Francis, Inderscience, GoogleShooler ..." by the combination of keywords "procurement, supply chain, sustainable development, performance, indicators, supplier's selection, review of the literature, criteria, economiec, social, environment", These words were carefully chosen to ensure that as many relevant articles as possible could be included.

In the literature, we identified the first study of supplier selection criteria was in 1966 (Dickson 1966), we followed the documents until 2018. Also we searched at international standards such as SCOR, GRI, OECD sustainable toolkit [31] and ISO $26000 \ldots$

We have observed an increase in the work published from the year 1966 to the beginning of 2018 .

The filtration process was carried out in three steps. In the first step, we found an initial list of 168 criteria that are related to SD, after we chose 34 criteria that are most relevant in the literature and finally, we defined 28 criteria that are related to the SSS process (fig.1).

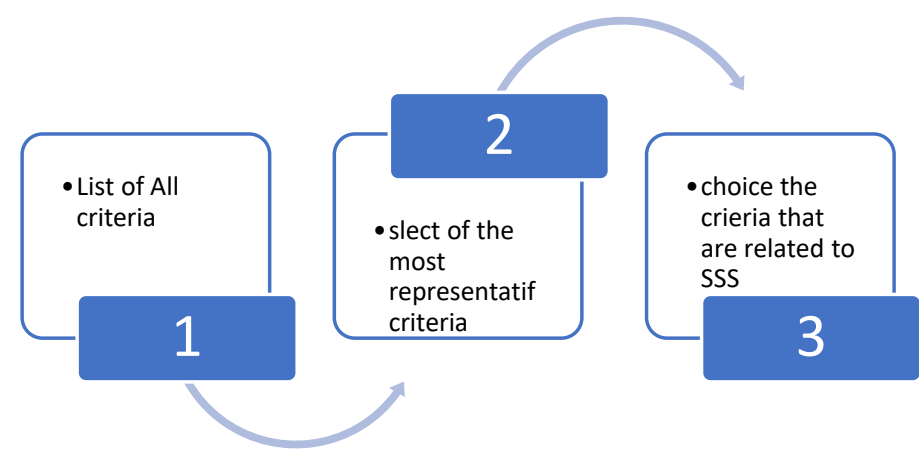

Figure 1: Follow-up methodology

A review of the literature and a database search were carried out to build a common list of SD criteria for the SS process and in international standards, as a result:

\section{Economic criteria}

The traditional model of supplier selection depended on economic criteria (quality, cost and time), but with increasing concern about environmental and social issues, other criteria are added in the purchasing decision. The economic criteria found in the literature for the selection of suppliers are:

- Innovation capacity $\left(\mathrm{C}_{1}\right)$ : Is the ability to bring new solutions or to improve an existing solution in order to be competitive.

- Production capacity $\left(\mathrm{C}_{2}\right)$ : The ability to meet customer needs.

- Technical and technological capacity $\left(\mathrm{C}_{3}\right)$ : The use of new techniques and technologies in production.

- $\operatorname{Cost}\left(\mathrm{C}_{4}\right)$ : This is the cost associated with purchasing the raw material or component provided.

- Deadlines $\left(\mathrm{C}_{5}\right)$ : This is the time needed to respond to an expressed need.

- Reliability $\left(\mathrm{C}_{6}\right)$ : Customer satisfaction in terms of product choice, quality or lead time.

- Financial $\left(\mathrm{C}_{7}\right)$ : Costs related to the design and/or development of products.

- Flexibility $\left(\mathrm{C}_{8}\right)$ : Is the ability to respond to situations and likely disruptions.

- Delivery $\left(\mathrm{C}_{9}\right)$ : Transport of goods and assurance of their delivery to the destination.

- Quality $\left(\mathrm{C}_{10}\right)$ : It is defined by standards such as ISO to satisfy expressed needs.

- Reactivity $\left(\mathrm{C}_{11}\right)$ : It is the ability to respond quickly to increasingly diverse needs in the global market.

- Customer references $\left(\mathrm{C}_{12}\right)$ : It is the development of references, testimonials and customer success.

\section{Environmental criteria}

Environmental criteria are aimed at making choices of products and services that minimize the exploitation and consumption of natural resources, avoid the production of waste and reduce the risk of contamination of the living environments arising from consumer habits and the whole Activities related to their life cycle. The environmental criteria found in the literature for the selection of suppliers are:

- Waste $\left(\mathrm{C}_{13}\right)$ : This is the waste from manufacturing.

- Emission $\left(\mathrm{C}_{14}\right)$ : These are the various gases and substances emitted from the manufacture and transport of products.

- Environmental label $\left(\mathrm{C}_{15}\right)$ : Quality labels to establish that if a product or actor has a reduced impact on the environment.

- Pollution $\left(\mathrm{C}_{16}\right)$ : Pollution emitted in air, soil and water due to production.

- Program $\left(\mathrm{C}_{17}\right)$ : These are the different programs and management policy for the protection of the environment.

- Recycling $\left(\mathrm{C}_{18}\right)$ : The reuse of raw materials. 
- Compliance with rules $\left(\mathrm{C}_{19}\right)$ : Respect for environmental and social requirements.

- Use of resources $\left(\mathrm{C}_{20}\right)$ : Materials used in the component supplied and the energy consumption during the manufacture of the product.

- Toxic or dangerous substances $\left(\mathrm{C}_{21}\right)$ : The use of hazardous materials in the manufacture of products.

\section{Social criteria}

Social criteria support the ethical management of staff at CS suppliers, equity and encourage the responsibility of suppliers. Social criteria are little discussed in the literature; research in the literature has resulted in:

- Human rights $\left(\mathrm{C}_{22}\right)$ : Are represented by the absence of forced labor and child labor, freedom of association and non-discrimination.

- Jobs and wealth $\left(\mathrm{C}_{23}\right)$ : Improving the standard of living by ensuring full employment and stable employment.

- Training, support and education $\left(\mathrm{C}_{24}\right)$ : All continuing training to ensure the development of human resources.

- Occupational health and safety $\left(\mathrm{C}_{25}\right)$ : This is the protection of workers against the risks and adaptation of the working environment to the physiological and psychological needs of workers.

- Working conditions $\left(\mathrm{C}_{26}\right)$ : Improvement of wages and respect for working time, rest periods, prayer periods, holidays, disciplinary practices and dismissals, maternity protection issues and such as access to drinking water, canteens and access to medical services.

\subsection{Proposed mathematical model for measuring supplier sustainability index}

We consider a manger that would like to select the best supplier who respects the three dimensions of SD. The following mathematical model allows decision-makers to choose the most sustainable supplier:

\section{Parameter}

$N_{n s} \quad$ Number of new solution

$N_{i s} \quad$ Number of improved solution

$Q_{s} \quad$ Quantity served

$Q_{d} \quad$ Quantity requested

$N_{n t} \quad$ Number of techniques and technologies in production renewed

$C_{\text {ost }} \quad$ Cost associated with the purchase of the raw material or component provides (USD)

$N_{d} \quad \begin{aligned} & \text { Number of days needed to respond to a expressed } \\ & \text { need }\end{aligned}$
$N_{c s} \quad$ Number of satisfied customers

$N_{t c} \quad$ Total number of customers

$C_{c d} \quad$ Costs related to product design and / or development (USD)

$I_{f l} \quad$ Index ability to react to situations and likely disturbances

$C_{\text {ostd }}$ Cost of transporting goods to destination (USD)

$N_{s} \quad$ Number of quality standards

$I_{r e} \quad$ Index of ability to respond very quickly to

$I_{\text {re }}$ increasingly diverse needs in the global market

$N_{g t} \quad$ Number of good testimonials

$N_{t t} \quad$ Total number of testimonials

$I_{w m} \quad$ Waste quantity index of product manufacturing

Quantity index of the different gases and substances

$I_{\text {egs }} \quad$ emitted from the manufacture and transport of products

$I_{q l} \quad$ Quality Label Index

$I_{p e} \quad$ Pollution index of air, soil and water due to production

$I_{p p} \quad$ Index of different programs and management policy for the protection of the environment

$I_{r m} \quad$ Index of reuse of raw materials

$I_{r r} \quad$ Index of compliance with environmental and social requirements

Index of quantity of materials (lead, chromium,

$I_{u r} \quad$ coal ...) and energy (gas, water, electricity ...) used during the production of the product

$I_{t d s} \quad$ Quantity index of hazardous or toxic materials in the product

$I_{h r} \quad$ Index of respect for human rights

$I_{j w}$ Improvement index for the standard of living of
employers

$I_{\text {tse }} \quad$ Index of continuing education to ensure the

$I_{\text {tse }}$ development of human resources

$N_{w a} \quad$ Number of employees injured

$N_{t w} \quad$ Total number of employees

$I_{c w} \quad$ Index of respect for working conditions

$I_{\text {eco }} \quad$ Index of economic dimension 
O. El Mariouli et al. / Advances in Science, Technology and Engineering Systems Journal Vol. 4, No. 2, 251-259 (2019)

$I_{e n v} \quad$ Index of environmental dimension

$I_{s o c} \quad$ Index of social dimension

$W_{i} \quad$ Weight associated with the criterion $C_{i}$

$W_{\text {eco }} \quad$ Weight associated with the economic dimension

$W_{\text {env }} \begin{aligned} & \text { Weight associated with the environmental } \\ & \text { dimension }\end{aligned}$

$W_{\text {soc }} \quad$ Weight associated with the social dimension

\section{Objective function}

In this paper, the objective function is the index of sustainability supplier. It is represented by set of SD criteria having a value limited between 1 and 0 . We use the ratio for facilitating the aggregation of the different elements in the objective.

The following equations represent the calculation of the set of SD criteria:

$C_{1}=\frac{N_{n s}+N_{i s}}{N_{n s}+N_{i s}+1}$

$C_{3}=\frac{Q_{S}}{Q_{D}}$

$C_{3}=\frac{N_{n t}}{N_{n t}+1}$

$C_{4}=\frac{1}{C_{\text {ost }}}$

$C_{5}=\frac{1}{N_{d}}$

$C_{6}=\frac{N_{c s}}{N_{t c}}$

$C_{7}=\frac{C_{c d}}{C_{c d}+1}$

$C_{8}=\frac{1}{I_{f l}}$

$C_{9}=\frac{1}{C_{\text {ostd }}}$

$C_{10}=\frac{N_{s}}{N_{s}+1}$

$$
C_{11}=\frac{1}{I_{r e}}, I_{r e}=\left\{\begin{array}{l}
1 \text { if Good } \\
2 \text { if Average }
\end{array}\right.
$$

$C_{12}=\frac{N_{g t}}{N_{t t}}$

$C_{13}=\frac{1}{I_{w m}}, I_{w m}=\left\{\begin{array}{l}1 \text { if Little } \\ 2 \text { if Average }\end{array}\right.$

$C_{14}=\frac{1}{I_{e g s}}, I_{e g s}=\left\{\begin{array}{l}1 \text { if Little } \\ 2 \text { if Average }\end{array}\right.$

$$
C_{18}=I_{r m} \quad, I_{r m}=\left\{\begin{array}{l}
1 \text { if Recyclable } \\
0 \text { if No }
\end{array}\right.
$$

$C_{19}=\frac{1}{I_{r r}}, I_{r r}=\left\{\begin{array}{l}1 \text { if Much } \\ 2 \text { if Average } \\ 3 \text { if Little }\end{array}\right.$ 


$$
\begin{aligned}
& C_{20}=\frac{1}{I_{u r}}, I_{u r}=\left\{\begin{array}{r}
1 \text { if Little } \\
2 \text { if Average } \\
3 \text { if Much }
\end{array}\right. \\
& C_{21}=I_{t d s}, I_{r m}=\left\{\begin{array}{l}
1 \text { if Recyclable } \\
0 \text { if No }
\end{array}\right. \\
& C_{22}=\frac{1}{I_{h r}}, I_{h r}=\left\{\begin{array}{l}
1 \text { if Good } \\
2 \text { if Average }
\end{array}\right. \\
& C_{23}=\frac{1}{I_{j w}}, I_{j w}=\left\{\begin{array}{l}
1 \text { if Good } \\
2 \text { if Average }
\end{array}\right. \\
& C_{25}=\frac{1}{N_{w a}}, I_{c w}=\left\{\begin{array}{l}
1 \text { if Good } \\
2 \text { if Average }
\end{array}\right. \\
& \begin{array}{l}
1 \text { if Much } \\
2 \text { if Average }
\end{array}
\end{aligned}
$$

After obtaining the criteria values, decision makers are asked to assign weights to the chosen criteria. Each criteria value is multiplied by its weight. We obtain three value represents economic, environmental and social indicator, respectively as follows:

$$
\begin{gathered}
I_{\text {eco }}=\frac{\sum_{i=1}^{12} W_{i} C_{i}}{12} \quad i=\{1,2, \ldots, 12\} \\
I_{\text {env }}=\frac{\sum_{i=13}^{21} W_{i} C_{i}}{9} \quad i=\{13,14, \ldots, 21\}
\end{gathered}
$$

$$
I_{s o c}=\frac{\sum_{i=22}^{26} W_{i} C_{i}}{5} \quad i=\{22,23, \ldots, 26\}
$$

In the end, the decision-makers are asked to choose the weights of the three dimensions of sustainable development according to their policy followed by the company, then each value of SD dimension indicator obtained by equation (27) to (29) are multiplied by these weight.

The sustainability performance score of the supplier is given by the following maximum function:

$$
\operatorname{Max} P=\frac{W_{e c o} I_{e c o}+W_{e n v} I_{e n v}+W_{s o c} I_{s o c}}{3}
$$

The MaxP equation represents the function of the developed model. The maximum value of the equation (30) is one.

\section{Constraints:}

- The sum of the weights in each dimension must not exceed the value 1 .

$Q_{S} \leq Q_{D}$

- The sum of the weights in each dimension must not exceed the value 1 .

$$
\sum_{i=1}^{12} W_{i}=1
$$

$\sum_{i=13}^{21} W_{i}=1$

$\sum_{i=22}^{26} W_{i}=1$

$W_{\text {eco }}+W_{e n v}+W_{s o c}=1$

- The sum of the weights of the dimensions of SD is equal to 1 .

$$
0 \leq C_{i} \leq 1 \quad \forall i=\{1,2, \ldots, 26\}
$$

\section{Data analysis}

A company $\mathrm{X}$ decides to choose the best supplier among five suppliers. Managers have chosen the weights of each criterion in such a way that: the sum of the weights of the criteria of each dimension is equal to one.

All criteria value under each of the three pillars are multiplied by their respective weights and aggregated as indicated by Equations (27) to (29). The result is three index 
Table 2: Index of environmental, economic and social dimensions

\begin{tabular}{|c|c|c|c|c|c|c|c|}
\hline Dimension & Criteria & Weight & Supplier1 & Supplier2 & Supplier3 & Supplier4 & Supplier5 \\
\hline \multirow{13}{*}{ Economic } & $\mathrm{C}_{1}$ & 0,101 & 0,500 & 0,600 & 0,700 & 0,800 & 0,900 \\
\hline & $\mathrm{C}_{2}$ & 0,079 & 0,200 & 0,400 & 0,600 & 0,800 & 1,000 \\
\hline & $\mathrm{C}_{3}$ & 0,106 & 0,500 & 0,600 & 0,700 & 0,800 & 0,900 \\
\hline & $\mathrm{C}_{4}$ & 0,115 & 0,910 & 0,920 & 0,930 & 0,940 & 0,950 \\
\hline & $\mathrm{C}_{5}$ & 0,095 & 0,167 & 0,200 & 0,250 & 0,333 & 0,500 \\
\hline & $\mathrm{C}_{6}$ & 0,098 & 0,500 & 0,600 & 0,700 & 0,800 & 0,900 \\
\hline & $\mathrm{C}_{7}$ & 0,061 & 0,917 & 0,929 & 0,941 & 0,950 & 0,980 \\
\hline & $\mathrm{C}_{8}$ & 0,053 & 0,333 & 0,500 & 0,500 & 1,000 & 1,000 \\
\hline & $\mathrm{C}_{9}$ & 0,051 & 0,005 & 0,006 & 0,007 & 0,010 & 0,011 \\
\hline & $C_{10}$ & 0,082 & 0,710 & 0,770 & 0,790 & 0,870 & 0,920 \\
\hline & $C_{11}$ & 0,079 & 0,500 & 0,500 & 1,000 & 1,000 & 1,000 \\
\hline & $\mathrm{C}_{12}$ & 0,080 & 0,850 & 0,880 & 0,900 & 0,980 & 1,000 \\
\hline & \multicolumn{2}{|c|}{$I_{\text {eco }}$} & 0,528376 & 0,595915 & 0,691638 & 0,701738 & 0,858031 \\
\hline \multirow{10}{*}{ Environment } & $\mathrm{C}_{13}$ & 0,112 & 0,333 & 0,500 & 0,500 & 1,000 & 1,000 \\
\hline & $\mathrm{C}_{14}$ & 0,115 & 0,333 & 0,333 & 0,500 & 0,500 & 1,000 \\
\hline & $\mathrm{C}_{15}$ & 0,133 & 0,000 & 0,000 & 1,000 & 1,000 & 1,000 \\
\hline & $\mathrm{C}_{16}$ & 0,137 & 0,333 & 0,333 & 0,500 & 0,500 & 1,000 \\
\hline & $\mathrm{C}_{17}$ & 0,130 & 0,333 & 0,333 & 0,500 & 0,500 & 1,000 \\
\hline & $\mathrm{C}_{18}$ & 0,074 & 0,000 & 0,000 & 1,000 & 1,000 & 1,000 \\
\hline & $\mathrm{C}_{19}$ & 0,154 & 0,333 & 0,333 & 0,500 & 0,500 & 0,500 \\
\hline & $\mathrm{C}_{20}$ & 0,074 & 0,333 & 0,333 & 0,333 & 0,333 & 0,500 \\
\hline & $\mathrm{C}_{21}$ & 0,071 & 0 & 0 & 0 & 1,000 & 1,000 \\
\hline & \multicolumn{2}{|c|}{$I_{e n v}$} & 0,240426 & 0,25913 & 0,555642 & 0,682642 & 0,886 \\
\hline \multirow{6}{*}{ Social } & $\mathrm{C}_{22}$ & 0,232 & 0,333 & 0,333 & 0,500 & 0,500 & 1,000 \\
\hline & $\mathrm{C}_{23}$ & 0,129 & 0,333 & 0,333 & 0,500 & 0,500 & 1,000 \\
\hline & $\mathrm{C}_{24}$ & 0,198 & 0,333 & 0,333 & 0,500 & 0,500 & 1,000 \\
\hline & $\mathrm{C}_{25}$ & 0,191 & 0,200 & 0,240 & 0,250 & 0,290 & 0,300 \\
\hline & $\mathrm{C}_{26}$ & 0,250 & 0,5 & 0,5 & 1,000 & 1,000 & 1,000 \\
\hline & \multicolumn{2}{|c|}{$I_{s o c}$} & 0,349347 & 0,356987 & 0,57725 & 0,58489 & 0,8663 \\
\hline
\end{tabular}

values representing the environmental, economic and social dimensions, respectively (Table2).

The enterprise $\mathrm{X}$ choice the scenario of weigh dimension like as:

$$
W_{e c o}=W_{e n v}=W_{s o c}=\frac{1}{3}
$$

The final sustainable performance indices of suppliers were used to rank the suppliers in the $\mathrm{X}$ enterprise (Table3), supplier5 is identified as the best sustainable supplier with $\mathrm{MaxP}=0,29$ (Fig2).

\section{Conclusion}

With the appearance of the new sustainable development concept in the last 20 years, industrial company have begun to 
Table 3: The sustainable performance indices of the supplier

\begin{tabular}{|l|l|l|l|l|l|}
\hline & \multicolumn{1}{|c|}{$I_{e c o}$} & \multicolumn{1}{|c|}{$I_{e n v}$} & \multicolumn{1}{|c|}{$I_{s o c}$} & sustainable performance & Rank \\
\hline Supplier1 & 0,528376 & 0,240426 & 0,349347 & 0,12423878 & 5 \\
\hline Supplier2 & 0,595915 & 0,25913 & 0,356987 & 0,13467022 & 4 \\
\hline Supplier3 & 0,691638 & 0,555642 & 0,57725 & 0,20272556 & 3 \\
\hline Supplier4 & 0,701738 & 0,682642 & 0,58489 & 0,21880778 & 2 \\
\hline Supplier5 & 0,858031 & 0,886 & 0,8663 & 0,29003678 & 1 \\
\hline
\end{tabular}

\section{sustainable performance}

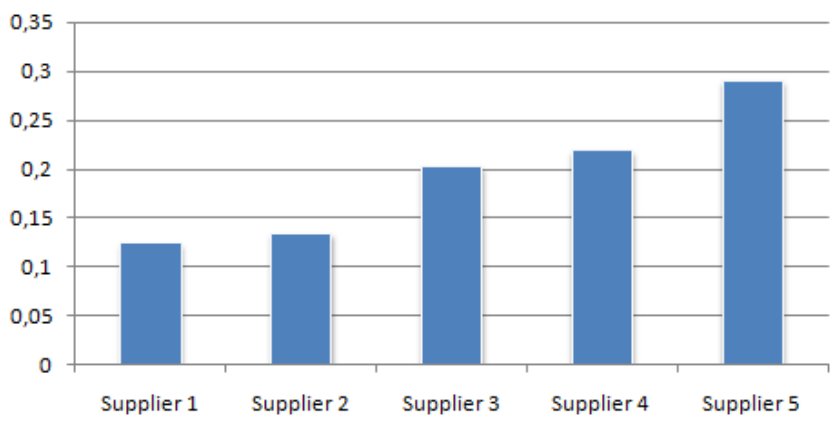

Figure 2: Sustainable performance of the supplier

integrate environmental and social concerns into the management of their activities in order to protect the company's durability and open up new markets. The process of integrating SD into the company starts with the selection of suppliers. In this paper, we have given a list that includes all the relevant criteria in the literature for the selection of suppliers. These criteria influence the functioning of all the other services of the company (transport, stock, production, etc.). In the last, we have presented an easy-to-use mathematical model for managers to measure vendor performance. Our developed model is simple to apply and can be used in any industrial enterprise to select the best sustainable supplier.

\section{References}

[1] Atefeh Amindousta, Shamsuddin Ahmeda, Ali Saghafiniab, Ardeshir Bahreininejada, Sustainable supplier selection: A ranking model based on fuzzy inference system, Applied Soft Computing 12 (2012) 1668-1677.

[2] Buyuközkan, G., Çifci, G., 2011. A novel fuzzy multi-criteria decision framework for sustainable supplier selection with incomplete information. Comput. Ind. 62, 164-174.

[3] X. Zhou, et al., Type-2 fuzzy multi-objective DEA model: An application to sustainable supplier evaluation, Appl. Soft Comput. J. (2016), http://dx.doi.org/10.1016/j.asoc.2016.04.038.

[4] Fallahpour, A., Udoncy Olugu, E., Nurmaya Musa, S., Yew Wong, K., Noori, S., A decision support model for sustainable supplier selection in sustainable supply chain management, Computers \& Industrial Engineering (2017), doi: http://dx.doi.org/10.1016/j.cie.2017.01.005.

[5] Dickson, G. W. (1966). An analysis of vendor selection systems and decisions. Journal of Purchasing, 2 (1), 28-41.

[6] Weber, C. A., Current, J. R., \& W. C. Benton (1991). Vendor selection criteria and methods. European Journal of Operational Research, 50, 2-18.

[7] Larson, P. D. (1993). Buyer-Supplier co-operation, product quality and total cost. International Journal of Physical Distribution \& Logistics Management, 24 (6), 4-10.

[8] Vonderembse, M., Tracey, M., Tan, C. L., \& E. J. Bardi (1995). Current purchasing practices and JIT: some of effects on inbound logistics. International Journal of Physical Distribution \& Logistics Management, 25 (3), 33-48.
[9] Verma, R., \& M. E. Pullma (1998). An analysis of the supplier selection process. International Journal of Management Science, 26 (6), 739-750.

[10] Katsikeas, C. S., Paparoidamis, N. G., \& E. Katsikea (2004). Supply source selection criteria: the impact of supplier performance on distributor performance. Indutrial Marketing Management.

[11] Aicha Aguezzoul, Pierre Ladet. S election et evaluation des fournisseurs : Crit_eres et m_ethodes. Revue fran_caise de gestion industrielle, Paris-La$\mathrm{D}$ efense : Association fran caise de gestion industrielle ; Montrouge : Centrale des revues, 2006, 2, pp.5-27.

[12] Emilie Baumann. Modèles d'évaluation des performances économique, environnementale et sociale dans les chaines logistiques. Gestion et management. INSA de Lyon, (2011).

[13] Tasseda Boukherroub. Int egration des objectifs du d eveloppement durable dans la gestion strat egique et tactique de la chaine logistique. Gestion et management. INSĀ de Lyon, 2013.

[14] Ozlem Gurel, A. Z. Acar, I. Onden, I. Gumus (2015). Determinants of the green supplier selection. Procedia - Social and Behavioral Sciences 181 ( 2015 ) $131-139$.

[15] Joanie Caron, Suzanne Durand, Hugo Asselin, (2016). Principles and criteria of sustainable development for the mineral exploration industry. Journal of Cleaner Production 119 (2016) 215-222.

[16] Wenyan Song, Zhitao X, Hu-Chen Liu, (2017). Developing sustainable supplier selection criteria for solar air-conditioner manufacturer: An integrated approach. Renewable and Sustainable Energy Reviews 79 (2017) 1461-1471.

[17] Marko Vasiljević, Hamed Fazlollahtabar, Željko Stevića, Slavko Vesković, (2018). A ROUGH MULTICRITERIA APPROACH FOR EVALUATION OF THE SUPPLIER CRITERIA IN AUTOMOTIVE INDUSTRY. Decision Making: Applications in Management and Engineering Vol. 1, Number 1, 2018, pp. 82-96. ISSN: 2560-6018. DOI: 10.31181/dmame180182v

[18] Panitas Sureeyatanapas, Kawinpob Sriwattananusart, Thanawath Niyamosothath, Weerapat Setsomboon, Sirawadee Arunyanart, Supplier selection towards uncertain and unavailable information: an extension of TOPSIS method, Operations Research Perspectives (2018), doi: 10.1016/j.orp.2018.01.005.

[19] Ashkan Memaria, Ahmad Dargib, Mohammad Reza Akbari Jokara, Robiah Ahmadc, Abd. Rahman Abdul Rahimc, (2019). Sustainable supplier selection: A multi-criteria intuitionistic fuzzy TOPSIS Method. Journal of Manufacturing Systems 50 (2019) 9-24.

[20] Chunguang Bai, Joseph Sarkis, (2010). Integrating sustainability into supplier selection with grey system and rough set methodologies. Int. J. Production Economics 124 (2010) 252-264.

[21] Hacer Guner Goren, A Decision Framework for Sustainable Supplier Selection and Order Allocation with Lost Sales, Journal of Cleaner Production (2018), doi: 10.1016/j.jclepro.2018.02.211.

[22] Konrad Zimmer, Magnus Fröhling \& Frank Schultmann (2015): Sustainable supplier management - a review of models supporting sustainable supplier selection, monitoring and development, International Journal of Production Research, DOI: 10.1080/00207543.2015.1079340.

[23] Ilgin MA, et al. Use of MCDM techniques in environmentally conscious manufacturing and product recovery: State of the art. J Manuf Syst (2015), http://dx.doi.org/10.1016/j.jmsy.2015.04.010.

[24] Babbar C, Amin SH. A multi-objective mathematical model integrating environmental concerns for supplier selection and order allocation based on fuzzy QFD in beverages industry. Expert Syst Appl 2018;92:27 - 38

[25] Jain, Vipul, Kumar Sameer, Kumar Amit, Chandra Charu. An integrated buyer initiated decision-making process for green supplier selection. J Manuf Syst 2016;41:256 - 65. 
[26] Kannan D, Govindan K, Rajendran S. Fuzzy Axiomatic Design approach based green supplier selection: a case study from Singapore. J Clean Prod 2015;96:194 - 208.

[27] Ghayebloo S, Tarokh MJ, Venkatadri U, Diallo C. Developing a biobjective model of the closed-loop supply chain network with green supplier selection and disassembly of products: the impact of parts reliability and product greenness on the recovery network. J Manuf Syst $2015 ; 36: 76-86$

[28] Govindan K, Rajendran S, Sarkis J, Murugesan P. Multi criteria decision making approaches for green supplier evaluation and selection: a literature review. J Clean Prod 2015;98:66 - 83.

[29] Banaeian, N., Mobli, H., Fahimnia, B., Nielsen, I.E., and Omid, M. (2018). Green supplier selection using fuzzy group decision making methods: A case study from the agri-food industry. Computers \& Operations Research 89, 337-347.

[30] Keshavarz Ghorabaee, M., Zavadskas, E.K., Amiri, M., and Esmaeili, A. (2016). Multi-criteria evaluation of green suppliers using an extended WASPAS method with interval type-2 fuzzy sets. Journal of Cleaner Production 137, 213-229

[31] OECD Sustainable Manufacturing Toolkit. Avalable online: http://www.oecd.org/sti/inno/ 48101937.pdf (accessed on 25 December 2014). 